\title{
MONTESQUIEU DAN MAKNA SEBUAH KEADILAN
}

\author{
Daya Negri Wijaya \\ Jurusan Sejarah, Universitas Negeri Malang \\ J1. Semarang No.5 Malang \\ email: daya.negri.fis@um.ac.id
}

\begin{abstract}
People face many injustice practices at present. This will be a national concern. Justice which should be guaranteed by the standing law does not execute as common. Montesquieu concerns on the justice and law. Government should look at a law as an independent power from the executive power. Therefore, law should be fitted with the concrete situation of a nation and should not be following the authority's will. Montesquieu with his justice spirit inspires the way of revolution. He makes an analogy of king and pope as the liars. They place people as a duping object. He is also claimed as one of philosophers in France. This paper will discuss the meaning of justice and its relation to the spirit of revolution.
\end{abstract}

Keywords: philosophy of law, the French revolution, the spirit of laws, the Persian letters

\begin{abstract}
Abstrak: Khalayak melihat berbagai tindak ketidakadilan yang mengemuka. Hal ini menjadi salah satu keprihatinan bangsa. Keadilan yang seharusnya dijamin oleh hukum tidak berjalan sebagaimana mestinya. Montesquieu sangat peduli dengan isu keadilan dan hukum. Pemerintah sudah seharusnya melihat hukum sebagai hal yang independen dari kekuasaan eksekutif. Oleh karena itu, hukum harus disesuaikan dengan situasi konkret sebuah bangsa dan bukan mengikuti kehendak penguasa. Montesquieu dengan semangat melawan ketidakadilan juga turut menginspirasi jalannya revolusi. Dia menganalogikan raja dan paus seperti tukang bohong. Mereka menjadikan rakyat sebagai obyek pembodohan.Dia juga dianggap sebagai salah satu filsuf berpengaruh di Prancis. Tulisan ini akan membahas makna keadilan dan relasinya pada semangat perjuangan revolusi.
\end{abstract}

Kata kunci: filsafat hukum, revolusi Prancis, semangat hukum, surat-surat Persia

Belantara Juni seharusnya dihiasi dengan pembudayaanatau pembumian nilai-nilai Pancasila. Akan tetapi, realitas yang dihadapi ternyata berbeda dengan pengharapan yang ada. Awal Juni hampir semua media cetak memberikan arti penting Pancasila namun ironisnya banyak pula yang membahas keadilan yang diperjualbelikan. Bahkan, salah satu media cetak nasional dengan tegas mempertanyakan eksistensi peradilan Indonesia. Praktik suap yang marak terjadi membuat keadilan menjadi barang yang langka (Kompas, 16 Juni 2016). Kasus jual beli perkara ternyata kian mengundang keprihatinan rakyat. Apa sebenarnya arti dari keadilan dan mengapa keadilan harus diperjuangkan ternyata begitu membingungkan. Ketika ternyata kita sulit menemukan titik terang dari persoalan ini, sudah selayaknya khalayak kembali membuka literasi klasik.
Klasik bukan berarti merujuk pada sesuatu yang kuno atau usang tetapi merujuk pada sesuatu yang relevan untuk berbagai zaman, lintas ruang, dan waktu (Wijaya, 2016:18). Salah satu literasi klasik terkait keadilan adalah dua karya dari Montesquieu, the Spirit of Laws dan the Persian Letters. Montesquieu memiliki nama lengkapCharles Louis de Secondat Baron de Montesquieu. Dia lahir tepat setahun setelah Revolusi Kejayaan Inggris di dekat kota Bordeaux, Prancis. Walaupun dia terlahir dalam keluarga miskin tetapi dia beruntung dapat mengenyam pendidikan tinggi berkat tangan sang paman, Jean Bastiste de Secondat. Dia selain sebagai pemikir politik ternyata juga mendalami hukum dan bahkan pernah menjadi praktisi hukum di pengadilan (Suhelmi, 2001:214).Menurut Shklar (1987:5), dia menangani peradilan seperti hukuman mati, 
transportasi ke koloni, dan kerja paksa selama bekerja di pengadilan Menarik kiranya untuk mengulas makna keadilan di tengah zaman yang bergolak seperti halnya pemikiran dan kehidupan Montesquieu.

\section{KEADILAN DAN KETIDAKADILAN BAGI MONTESQUIEU}

Montesquieu memiliki kepribadian yang sangat unik. Dia menghabiskan banyak waktunya bukan hanya dengan melihat tata negara baik politik maupun hukum di Prancis tetapi juga membandingkan apa yang ada di daerah lain. Jiwanya yang gelisah melihat kenyataan ketidakadilan yang diterima rakyat dan kesewenangan penguasa telah membawanya mengunjungi pusat-pusat peradaban Barat seperti Wina, Venezia, Firenze, Roma, dan Napoli. Dia juga berkelana lama ke Inggris, Belanda, dan Jerman. Di tempat-tempat tersebut ia belajar dan menyelidiki lembaga-lembaga politik setempat. Berbagai pengalaman itu yang nantinya membawanya pada apa penyebab dari ketidakadilan dan bagaimana keadilan tersebut hadir di tengah masyarakat.

Montesquieu menganggap sifat alamiah manusia adalah bersikap adil namun karena situasi sosial tertentu, dia mulai memilih untuk bersikap adil atau tidak adil. Montesquieu (1992:8-14) menggambarkan prinsip keadilan dalam kisah kaum Troglodit. Kaum Troglodit, suku kecil di negeri Arab, hidup dengan begitu jahat dan buas serta di antara mereka tiada prinsip persamaan dan kesetaraan. Mereka memiliki seorang raja yang memperlakukan mereka dengan sangat keras. Hal ini dilakukan untuk memperbaiki sifat buruk mereka. Rakyat kemudian berkomplot dan memberontak pada raja. Mereka berhasil menguasai kerajaan dan membantai seluruh keluarga raja. Mereka kemudian bersepakat untuk membuat dewan perwakilan tetapi tidak lama berselang mereka juga membantainya. Mereka kemudian memilih hidup dengan bebas. Mereka terus mengikuti sifat-sifat liar mereka. Mereka menjaga kepentingan pribadi dan mengabaikan kepentingan orang lain.

Mereka mulai hidup secara terpisah dan tiada komunikasi antara masyarakat di dataran tinggi dan di dataran rendah. Ketika musim kering berjalan lama, tanah di dataran tinggi kekurangan air dan gagal panen terjadi. Kelaparan melanda masyarakat dataran tinggi dan masyarakat dataran rendah yang subur makmur tidak mau membagi hasil pertanian mereka. Rakyat dataran tinggi hampir semua musnah karena kekejaman rakyat yang lain. Ketika musim berganti, hujan mulai turun tiada jeda. Dataran tinggi mulai mendapat kesuburan tanahnya sedangkan tanah dataran rendah terendam air. Rakyat mulai menjerit kelaparan tapi mereka mendapat respon serupa dari apa yang mereka lakukan pada rakyat dataran tinggi. Rakyat akhirnya musnah karena sifat serakahnya.

Namun, di negeri itu hanya ada dua manusia yang sangat berbeda. Mereka memiliki rasa kemanusiaan, keadilan, dan kebajikan. Mereka terus memupuk anak-anaknya dengan kepentingan pribadi harus di tengah-tengah kepentingan umum. Keinginan untuk melepaskan diri dari hal itu akan membawa masyarakat pada kehancuran. Kebajikan sama sekali tidak dipaksakan dan bukanlah suatu latihan yang melelahkan. Keadilan untuk orang lain adalah kedermawanan kita. Mereka kemudian menyaksikan anak-anaknya tumbuh seperti mereka. Jumlah mereka terus meningkat dan mereka mengingatkan generasi penerusnya pada kemusnahan generasi mereka sebelumnya. Ketamakan dan keserakahan menjadi suatu yang asing bagi mereka. Mereka selalu memberi dan bagi yang memberi pasti akan mendapat keberuntungan. Mereka hidup makmur dengan hasil panen dan ternak mereka yang dianggap milik bersama.

Keadilan akan terjamin dengan adanya hukum. Hukum tersebut harus disesuaikan dengan situasi konkret sebuah bangsa. Montesquieu (2015:93) berpendapat bahwa sebuah hukum harus disesuaikan dengan perilaku khas orangorang yang dituju oleh si pembuat hukum. Suatu hal yang mustahil apabila hukum suatu bangsa akan cocok bagi bangsa lainnya. Jika bagi Montesquieu (2015:93) hukum adalah akal pikiran manusia maka bagi Huijbers (1982:274) hukum adalah perwujudan keadilan dalam hidup bersama manusia. Makna tersebut akan tercapai apabila prinsip-prinsip keadilan direalisasikan dalam hukum positif. Realisasi hukum positif tentunya harus didasarkan pada prinsip-prinsip suatu pemerintahan. Menurut Huijbers (1982:87), terdapat tiga prinsip suatu pemerintahan yang dikemukakan oleh Montesquieu yakni monarki beralaskan kehormatan, republik beralaskan kebajikan sipil, dan despotisme beralaskan 
ketakutan. Bentuk yang paling cocok pada suatu daerah tergantung pada situasi suatu bangsa. Setiap warga negara bertindak harus mengikuti hukum yang berlaku, baik hukum perdata maupun hukum pidana.

Dalam prinsip trias politica, dia memperkenalkan kekuasaan yudikatif sebagai pengganti dari kekuasaan federatif Locke. Dia merasa kekuasaan hakim harus berdaulat artinya pemimpin negara tidak berhak campur tangan dalam bidang ini. Prinsip kedaulatan kekuasaan yudikatif sangat mendorong perkembangan negara hukum. Kesewenangan hukum pada dasarnya terjadi karena ketiadaan pemisahan kekuasaan yang jelas. Mereka yang membuat undang-undang adalah mereka yang menjalankan roda pemerintahan. Apa yang mereka kehendaki menjadi hukum yang ditaati oleh rakyat. Apabila kekuasaan kehakiman bersatu dengan kedua kekuasaan yang lain maka hakim akan bertindak dengan keras dan menindas (Suhelmi, 2001:230). Keadaan di Prancis menggambarkan kekuasaan yang korup dan mempermainkan rakyat.

Bagi Montesquieu (1992:21-22), rakyat Prancis tak ubahnya menjadi objek permainan sulap raja dan paus. Raja Prancis adalah raja yang paling berkuasa di Eropa. Dia tidak memiliki tambang emas seperti raja Spanyol tetapi kekayaannya jauh melebihi raja Spanyol. Kekayaannya tidak lain bersumber dari sifat congkak rakyatnya. Mereka banyak membeli gelar-gelar kebangsawanan dan kehormatan istana. Dengan penjualan tersebut raja dapat membayar para prajuritnya, membangun kampkamp militer, dan mempersenjatai kapal-kapal perangnya. Raja berhasil memerintah rakyatnya dengan jalan menguasai cara berpikir rakyatnya. Dia dapat dengan mudah mengutarakan 1 koin emas sama nilainya dengan dua dan dia juga dengan mudah meyakinkan rakyat bahwa kertas adalah uang. Rakyat juga diperdayai bahwa raja dapat menyembuhkan segala macam penyakit. Namun, cara berpikir raja sangat dipengaruhi oleh paus.

Paus adalah pesulap kedua. Dia dengan mudah meyakinkan angka tiga sama dengan satu (konsep trinitas), roti yang kita makan bukan roti tetapi tubuh Yesus, dan anggur yang kita minum bukan anggur tetapi darah Yesus. Paus dengan begitu korup memaksa raja beserta rakyatnya meyakini apa yang mereka sampaikan. Jika mereka tidak meyakininya maka hukuman berat akan menimpa mereka kelak. Bahkan, seorang raja dapat melegitimasikan kekuasaannya setelah mendapatkan restu dari paus. Para raja lebih taat pada paus daripada bangsa serta rakyatnya. Paus dan para uskupnya membuat berbagai macam hukum agama agar para raja dan rakyat mematuhi segala kehendak paus tersebut.

Mereka menggunakan agama sebagai kendaraan dalam mencapai kepentingan pribadi. Pada hakikatnya agama sama sekali tidak membutuhkan cara-cara yang keras untuk mempertahankan diri. Montesquieu (1992:46) berujar "manusia dapat melakukan ketidakadilan karena ia berkepentingan untuk melakukannya dan karena ia lebih memikirkan diri sendiri daripada kepuasan orang lain". Fungsi agama harus dimanipulasi dalam membangun suatu negara. Pada konteks ini, agama hanya diperkenankan sejauh agama dapat memperkokoh struktur nilainilai kekuasaan negara. Agama harus diabdikan demi kebesaran, kesatuan, dan kejayaan bangsa. Agama yang tidak memiliki fungsi seperti itu tidak diakui keberadaannya (Suhelmi, 2001:218).

\section{MONTESQUIEU DAN REVOLUSI PRANCIS}

Belajar dari pemikiran dan apa yang dilakukan oleh Montesquieu, khalayak tentunya mulai merenungkan apa sebenarnya hakikat filsafat. Filsafat bukan hanya harus dipahami sebagai penafsiran atas dunia tetapi juga sebagai ilmu kritis yang mengubah jalannya dunia. Menurut Magnis-Suseno (1992:17), filsafat tidak mempertentangkan apa hakikatnya tetapi filsafat pada hakikatnya membantu masyarakat dalam memecahkan masalah-masalah kehidupan. Montesquieu sebagai seorang filsuf sekaligus pemikir juga tertarik untuk menyelesaikan permasalahan masyarakat yang dihadapi. Dia melihat bagaimana rakyat hidup dengan penindasan baik oleh para bangsawan maupun oleh gereja.Beragam kesengsaraan inilah yang kemudian mendorong kaum borjuis dan rakyat untuk merubah tatanan politik Prancis. Perubahan yang mengubah semua tatanan kehidupan masyarakat dikenal sebagai Revolusi Prancis.

Revolusi Prancis adalah konsekuensi logis dari ketidakmampuan suatu pemerintahan dalam mengelola rakyatnya. Namun, dalam konteks Revolusi Prancis terdapat suatu hal yang menarik. Perubahan tersebut bukan hanya terjadi karena 
kemelaratan atau penderitaan rakyat tetapi juga karena kepentingan golongan yang terdesak atau terancam oleh kesewenangan raja, yakni kaum borjuis. Kaum menengah inilah yang kemudian begitu intens dalam melakukan kritisi pada kinerja Louis XVI dan Maria Antoinette yang oleh rakyat dijuluki sebagai Madamme Defisit karena menghamburkan uang rakyat. Montesquieu bersama dengan Voltaire terus mengobarkan semangat perjuangan ini. Jika Voltaire memberikan kritik tajam pada posisi rohaniawan yang selalu berdiri membela raja maka Montesquieu dengan beragam pamfletnya melawan rencana pemerintah untuk meregulasi keun anggur lokal. Selain itu, Montesquieu melihat kekuasaan harus dipisahkan menjadi tiga kekuasaan yakni legislatif, eksekutif, dan yudikatif serta ketiganya harus bertanggungjawab pada rakyat bukan pada raja. Namun, keduanya serta kaum oposisi yang lain secara semena-mena dimasukkan ke penjara Bastille oleh raja.

Hal ini diperparah dengan pemberlakuan pajak yang hanya dibebankan pada kaum tani sedangkan kaum bangsawan dan rohaniawan bebas dari pajak (Romein, 1956:132-133). Rasa ingin bebas di kalangan rakyat meningkat seiring dengan tersebar luasnya tulisan dari JJ Rousseau tentang kontrak sosial dan kedaulatan rakyat. Rousseau berargumen bahwa kebebasan adalah suatu keadaan tidak terdapatnya keinginan manusia untuk menaklukan sesamanya. Manusia merasa bebas dari ketakutan akan kemungkinan terjadinya penaklukan atas dirinya baik secara persuasif maupun kekerasan. Selain itu, dia juga beragumen bahwa manusia bebas adalah manusia yang patuh pada hukum dan peraturan tetapi tidak menjadikan dirinya budak sehingga kebebasan yang dimiliki tidak mengarah pada anarki sosial. Manusia bebas inilah yang kemudian bersepakat untuk membentuk suatu kekuasaan bersama. Kekuasaan bersama inilah yang kemudian disebut sebagai kedaulatan rakyat. Tiap individu yang menyerahkan haknya atau kebebasannya tidak kehilangan keduanya tetapi negara yang kemudian bertugas mengayomi setiap individu dalam negara dan jika negara menyimpang dari kehendak umum maka negara akan mengalami krisis (Suhelmi, 2001:249-252).

Rakyat kemudian tergerak dan menyerbu Penjara Bastille (penjara istana) yang dianggap sebagai simbol kesewenangan raja. Mereka membebaskan seluruh tahanan politik dan menyuarakan perubahan. Raja, bangsawan, dan rohaniawan menyetujui tuntutan rakyat mengenai pembatasan kekuasaan mereka. Tidak berselang lama raja melakukan kekerasan pada rakyat yang secara langsung menimbulkan kemarahan dari rakyat. Hal ini diperpanjang dengan inisiatif raja yang ingin mengembalikan kedaulatan dengan mencari perlindungan ke Austria dan Prusia. Namun dalam perjalanan, rakyat segera mengenali mereka dan dituntut karena berkhianat dari kesepakatan bersama. Raja dan ratu kemudian diadili dengan dipenggal kepalanya di guillotine.

Keresahan dan ketakutan rakyat semakin diperparah dengan berbagai kalangan yang melakukan kontrarevolusi. Para petani Vendee, daerah Prancis Barat, mengangkat senjata melawan republik. Mereka melakukan perang gerilya demi agama, royalisme, dan cara hidup tradisional mereka. Di pojok-pojok lain, para federalis memberontak di provinsi-provinsi, keberatan atas kekuasaan yang dipegang oleh pemerintah pusat di Paris, Republik tidak mampu mengendalikan banyak bagian negeri (Perry, 2014:23).

Revolusi terus berjalan secara radikal. Kaum Girondin sebagai kelompok dominan di konvensi nasional digantikan oleh kaum Jacobin. Kaum Jacobin dianggap mampu untuk menyelesaikan permasalahan republik seperti bahaya akan serbuan asing, pemberontakan dalam negeri, dan krisis ekonomi. Walaupun sama-sama berasal dari kalangan borjuis namun kaum Girondin menentang campura tangan pemerintah dalam urusan bisnis dan kaum Jacobin mendukung pengendalian pemerintahan pada krisis ekonomi. Kaum Jacobin sangat didukung oleh Sans-Cullote (pemilik toko kecil dan pekerja upahan). Oleh karena itu, dengan pendukung mayoritas kaum Jacobin mampu untuk menguasai konvensi dan menahan kaum Girondin pada tanggal 2 Juni 1793 (Perry, 2014:24).

Kaum Jacobin kemudian terus melakukan pembaharuan. Mereka mengeluarkan konstitusi yang memuat deklarasi hak-hak baru, memberi hak pilih bagi semua pria dewasa dan bukan lagi bagi siapa yang membayar pajak. Mereka juga ingin untuk menyelenggarakan pendidikan gratis. Selain itu, mereka mengeluarkan hukum maksimum yang menetapkan harga-harga roti dan barang-barang pokok lainnya dan menaikkan upah untuk menghentikan inflasi. Berbagai kebijakan ini yang nantinya menyentuh hati rakyat. Rakyat diyakinkan untuk dapat berjuang bersama 
menghadapi kehadiran musuh baik orang asing maupun orang dalam negeri. Pribadi yang sangat penting dalam perjuangan ini adalah Maximillien Robespierre (Perry, 2014:26).

Pemerintahan Robespierre terus mendesak dan menggempur siapapun yang melawan republik. Kaum Sans-Cullote juga akhirnya harus merasakan hukuman mati walaupun mereka pendukung utama kaum Jacobin. Kaum Jacobin bukan bermaksud melakukan teror tetapi berusaha membangun suatu kediktatoran untuk menyelamatkan republik dan revolusi. Harga mahal memang harus dibayar. Mereka membela republik tetapi banyak nyawa rakyat yang melayang. Robespierre dianggap sebagai orang yang sangat bertanggungjawab atas hal ini. Dia kemudian diadili diatas guillotine. Kepemimpinan kemudian beralih ke tangan para borjuis pemilik modal yang ingin membersihkan kaum Jacobin dari konvensi. Tanpa disadari mereka melakukan kesalahan serupa yang dilakukan oleh Jacobin. Pada akhir 1795, kekuasaan beralih pada kaum Directory yang dibebani oleh perang, kemerosotan ekonomi, dan kerusuhan dalam negeri. Mereka mampu meremukkan semua pemberontakan sanscullote serta kaum yang ingin memulihkan monarki. Ketika militer menekan maka kaum Directory melemah. Kaum militer kemudian mengontrol jalannya kekuasaan. Salah satu dari mereka adalah Napoleon Bonaparte dan dia yang membawa revolusi ke arah yang berbeda (Perry, 2014:29).

Napoleon tidak memilih republikanisme maupun demokrasi dari Jacobin; namun, dia menganut tradisi despotisme abad kedelapan belas yang tercerahkan. Seperti para despot yang melakukan pembaruan, Napoleon mengagumi keseragaman dan efisiensi administratif, tidak senang dengan feodalisme, penghambatan religius, ketidaksamaan warga negara, lebih menyukai pengaturan pemerintah atas perdagangan dan industri. Dia melihat dalam despotisme tercerahkan suatu alat untuk menjamin kestabilan politik dan memperkuat negara. Napoleon melestarikan

\section{DAFTAR RUJUKAN}

Huijbers, T. 1982. Filsafat Hukum dalam Lintasan Sejarah. Yogyakarta: Kanisius Magnis-Suseno, F. 1992. Filsafat Sebagai Ilmu Kritis. Yogyakarta: Kanisius capaian-capaian revolusi seperti kesamaan berdasarkan hukum, karier terbuka bagi orang yang berbakat, dorongan terhadap pendidikan sekuler, dan pelemahan kekuasaan kaum imam (Perry, 2014:31).

Napoleon berhasil memberikan Prancis pemerintahan pusat yang kuat dan keseragaman administratif. Tentara dinas memiliki tugas dalam menghubungkan setiap desa dan menyatukan seluruh bangsa secara umum. Negara yang terpusat ini cocok dengan hasrat Napoleon akan pemerintahan yang tertib dan administrasi yang rasional. Napoleon membutuhkan dana dari pajak untuk membiayai militer dalam memadamkan pemberontakan dan perang di luar negeri. Napoleon juga memakai alat-alat polisi negara untuk mencegah adanya kritik yang berlebihan dan mendongkrak dukungan rakyat untuk kebijakankebijakan dan orang-orangnya. Opini publik dibentuk sedemikian rupa untuk mendukung pemerintahannya termasuk pers dan koran menjadi juru bicara pemerintah (Perry, 2014:32).

\section{SIMPULAN}

Keadilan memang menempati posisi yang membingungkan. Pada satu sisi, rakyat merasa mendapatkan keadilan, tetapi pada sisi yang lain adapula rakyat yang merasa mendapatkan ketidakadilan. Hal ini tentu terlihat dari praktik peradilan yang sedang hangat diperbincangkan. Keadilan terlihat samar karena semua pihak berjuang melakukan pembenaran. Oleh karena itu, wajar apabila kita harus merenung dan melihat pada apa yang telah berlalu. Salah satu pemikir yang peduli pada keadilan dan memperjuangkannya adalah Montesquieu. Dia melihat bahwa keadilan akan terjamin dengan adanya hukum. Hukum tersebut harus disesuaikan dengan situasi konkret sebuah bangsa. Apa yang ada dalam dan tujuan dari sebuah pemerintahan harus dilihat dari perkembangan sebuah bangsa itu sendiri.
Montesquieu. 2015. The Spirit of Laws: DasarDasar Ilmu Hukum dan Ilmu Politik. Bandung: Nusamedia

Montesquieu. 1992. Surat-Surat dari Persia. Jakarta: Dian Rakyat 
84 Jurnal Ilmiah Pendidikan Pancasila dan Kewarganegaraan, Th. 1, Nomor 2, Desember 2016

Peradilan Akuntabel, Mungkinkah?. Kompas, 16 Juni 2016, Halaman 5

Perry, M. 2014. Peradaban Barat: Dari Revolusi Prancis sampai Zaman Global. Yogyakarta: Kreasi Wacana

Romein, J. 1956. Aera-Eropa: Peradaban Sebagai Penyimpangan dari Pola Umum. Bandung-Jakarta-Amsterdam: PT Ganaco
Skhlar, J. 1987. Montesquieu. Oxford: Oxford University Press

Suhelmi, A. 2001. Pemikiran Politik Barat: Kajian Sejarah Perkembangan Pemikiran Negara, Masyarakat, dan Kekuasaan. Jakarta: Gramedia Pustaka Utama

Wijaya, D.N. 2016. "Jean-Jacques Rousseau dalamDemokrasi". JurnalPolitik Indonesia. Vol.1, No.1, (2016):16-31 